\title{
WORKSHOP PENYUSUNAN SILABUS DAN RPP BAGI GURU-GURU SMA/SMK MUHAMMADIYAH SE-KABUPATEN GUNUNGKIDUL
}

\author{
Oleh: Sunaryo dan Afit Istiandaru \\ Universitas Ahmad Dahlan Yogyakarta \\ E-mail: sunaryo.bener@yahoo.com \\ E-mail: afit.istiandaru@ pmat.uad.ac.id
}

\section{Ringkasan}

Salah satu kegiatan penting dalam merencanakan pembelajaran adalah menyusun silabus dan rencana pelaksanaan pembelajaran (RPP). Penerapan Kurikulum 2013 membuat guru harus menyesuaikan diri dalam menyusun silabus dan RPP berpendekatan saintifik. Guru-guru matematika SMA/SMK Muhammadiyah di Kabupaten Gunungkidul merupakan target sasaran kegiatan pengabdian kepada masyarakat yang tepat mengingat mereka belum pernah mendapatkan bimbingan teknis yang memadai. Tujuan kegiatan pengabdian ini adalah untuk melatih dan memotivasi guru agar mampu menyusun silabus dan RPP yang ideal. Kegiatan pengabdian dilaksanakan dalam dua tahapan, yaitu workshop dan pendampinga. Hasil kegiatan pengabdian menunjukkan bahwa para guru telah berusaha mencoba menerapkan silabus dan RPP hasil workshop dan kegiatan mandiri dengan baik. Adapun umpan balik yang diperoleh menunjukkan bahwa pada tema workshop sesuai dengan kebutuhan peningkatan profesionalisme guru dan optimis tujuan workshop dapat tercapai. Daya dukung workshop berupa fasilitas ruang maupun fasilitas pendukung cukup memadai sehingga workshop bisa berjalan dengan lancar, baik, tepat waktu, dan menyenangkan. Peserta sangat mendukung adanya pelatihan lanjutan.

Kata Kunci: silabus, RPP, Kurikulum 2013, pengembangan profesionalisme guru.

\section{A. PENDAhULUAN}

Banyak faktor yang menentukan kualitas pendidikan, namun guru tetap dipandang sebagai faktor penentu utama, karena guru yang memegang kendali pembelajaran, menentukan arah penca-paian tujuan pembelajaran, dan mengelola pembelajaran siswa (Amir, 2013; Kunandar, 2007; Jalal, 2007). Konsekuensi hal tersebut adalah bahwa guru dituntut untuk mampu membelajarkan siswa dengan baik.

Salah satu kompetensi yang harus dimiliki guru adalah kompetensi profesional. Kemampuan profesional adalah kemampuan yang berkaitan dengan tugas-tugas guru sebagai pembimbing, pendi-dik, dan pengajar. Untuk bisa membimbing, mendidik, dan mengajar dengan baik, guru harus mam-pu merencanakan pembelajaran dengan baik pula. Salah satu kegiatan penting dalam merencanakan pembelajaran adalah menyusun silabus dan rencana pelaksanaan pembelajaran. Kedua dokumen tersebut merupakan pedoman para guru untuk menyelenggarakan pembelajaran yang berkualitas.

Kegiatan workshop penyusunan silabus dan RPP merupakan hal yang lazim dilakukan dalam bentuk in-house training, terutama di sekolah-sekolah negeri. Kegiatan ini biasanya difasilitasi oleh dinas pendidikan melalui sekolah masing-masing dan didampingi oleh pengawas sekolah. Berbeda dengan sekolah negeri, para guru di sekolah swasta belum tentu dapat mengikuti pelatihan tersebut, padahal sekolah swasta juga memiliki tanggung jawab menyelenggarakan pembelajaran yang ber-kualitas bagi para siswanya. Salah satunya di sekolah-sekolah Muhammadiyah di Kabupaten Gu-nungkidul, 
para guru masih membutuhkan pelatihan menyusun silabus dan RPP yang berkualitas agar dapat merencanakan pembelajaran dengan baik. Hal ini menjadi tanggung jawab moral bagi aka-demisi di perguruan tinggi Muhammadiyah untuk mendampingi para guru tersebut agar dapat meningkatkan kemampuannya. Oleh karena itu, kami mengusulkan kegiatan pengabdian kepada masyarakat berupa workshop perencanaan pembelajaran bagi guru-guru SMA/SMK Muham-madiyah se-Kabupaten Gunungkidul. Tujuan kegiatan ini adalah untuk: (1) melatih para guru untuk menyusun silabus dan RPP yang ideal, dan (2) memotivasi guru untuk mampu merancang pembe-lajaran yang berkualitas.

Kurikulum 2013 mengamanatkan agar guru menerapkan pendekatan saintifik dalam pembe-lajaran. Pendekatan saintifik dalam pembelajaran meliputi menggali informasi melalui pengamatan, bertanya, dan percobaan. Peraturan Menteri Pendidikan dan Kebudayaan Republik Indonesia Nomor 81A Tahun 2013 tentang implementasi kurikulum pada Lampiran IV memberikan penjelasan pelak-sanaan pembelajaran menggunakan pendekatan saintifik. Pembelajaran hendaknya memberikan pengalaman belajar melalui kegiatan: mengamati, menanya, mengumpulkan informasi, mengasosia-si, dan mengkomunikasikan (Kemdikbud, 2013).

Untuk dapat membelajarkan siswa menggunakan pendekatan saintifik, guru membutuhakan perencanaan yang baik. Mulyasa (2009:5) mengemukakan bahwa dalam melaksanakan pembela-jaran, guru harus menyiapkan perangkat pembelajaran yang terdiri dari silabus, rencana pelaksanaan pembelajaran (RPP), lembar kerja siswa (LKS), buku siswa, dan instrumen penilaian yang mencakup aspek kognitif, afektif, dan psikomotorik. Sedangkan dalam kurikulum 2013, disebutkan pula bahwa guru juga mempunyai buku guru sebagai acuan pembelajaran. Silabus merupakan matriks yang digunakan sebagai acuan pengembangan RPP. Silabus memuat identitas mata pelajaran, SK, KD, materi pembelajaran, kegiatan pembelajaran, indikator pencapaian kompetensi, penilaian, alokasi waktu, dan sumber belajar. RPP adalah rencana yang menggambarkan prosedur dan pengorganisas-ian pembelajaran untuk mencapai tujuan pembelajaran yang telah ditetapkan.

\section{B. METODE PELAKSANAAN}

Sasaran kegiatan ini adalah guru-guru SMA/SMK Muhammadiyah se- Kabupaten Gunung-kidul, Daerah Istimewa Yogyakarta. Berdasarkan data yang pernah dihimpun, terdapat 15 SMA/SMK Muhammadiyah di Kabupaten Gunungkidul. Kegiatan pengabdian ini diikuti oleh ma-sing-masing 1 guru yang berasal dari 12 SMA/SMK Muhammadiyah di Kabupaten Gunungkidul. Secara umum, sekolah masih berada pada transisi penggunaan KTSP menuju penggunaan Kuri-kulum 2013.

Kegiatan pengabdian dilaksanakan dalam dua tahapan, yaitu workshop dan pendampingan. Materi workshop meliputi: (1) format silabus berdasarkan kurikulum 2013; (2) format RPP berdasar-kan kurikulum 2013; (3) menyusun indikator yang operasional; (4) menjabarkan topik materi sesuai $\mathrm{KD}$; (5) menentukan metode dan aktivitas pembelajaran; (6) memilih bentuk penilaian yang seim-bang pada ranah kognitif, afektif, dan psikomotor; (7) merancang kegiatan apersepsi; dan (8) meran-cang kegiatan belajar yang mencerminkan pendekatan saintifik. Sedangkan metode pelaksanaan workshop 
Diterbitkan oleh Lembaga Pengabdian kepada Masyarakat

Universitas Ahmad Dahlan Yogyakarta

diuraikan menjadi: (1) penyampaian pengantar pentingnya merancang pembelajaran dengan baik; (2) paparan materi; (3) workshop menyusun silabus dan RPP; dan (4) umpan balik.

\section{HASIL, PEMBAHASAN, DAN DAMPAK}

Kegiatan workshop dilaksanakan pada tanggal 18 Mei 2017. Selanjutnya, peserta melaksa-nakan kegiatan mandiri pada bulan Juni-Juli 2017 dan ditindaklanjuti dengan kegiatan pendam-pingan (kunjungan) ke sekolah-sekolah sasaran untuk memantau perkembangan kegiatan mandiri pada tanggal 21 Juli 2017. Secara umum, kegiatan workshop berjalan dengan lancar. Penulis men-dapatkan data umpan balik dari peserta workshop untuk memberikan penilaian dari 1 (kualitas teren-dah) hingga 5 (kualitas tertinggi) terhadap aspek-aspek workshop sebagaimana disajikan pada Tabel 1 berikut.

Tabel 1 Umpan Balik Peserta Workshop

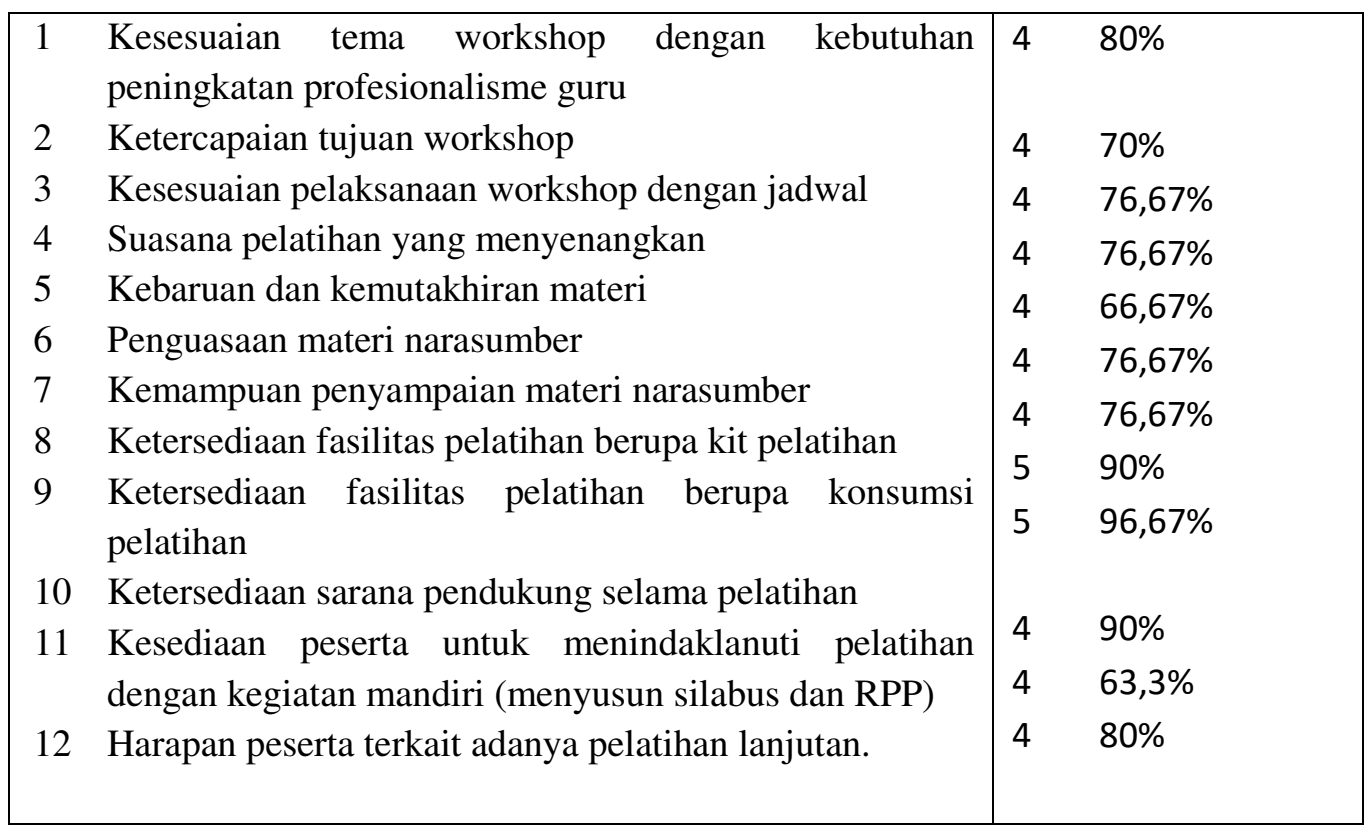

Sumber: Olah data feedback pengabdian 2017

Pada Tabel 1 di atas, terlihat bahwa peserta merespon dengan baik workshop yang diselenggarakan. Peserta berpendapat bahwa pada tema workshop sesuai dengan kebutuhan peningkatan profesionalisme guru dan optimis tujuan workshop dapat tercapai. Menurut peserta, workshop berjalan dengan baik, tepat waktu, dan menyenangkan. Daya dukung workshop berupa fasilitas ruang maupun fasilitas pendukung cukup memadai sehingga workshop bisa berjalan dengan lancar. Peserta sangat mendukung adanya pelatihan lanjutan.

Aspek yang direspon kurang dari aspek-aspek yang lain adalah mengenai kebaruan materi dan komitmen peserta untuk menerapkan di sekolah pascaworkshop. Kedua aspek tersebut hanya direspon $67,67 \%$ dan $60 \%$ dari keseluruhan peserta yang menjawab berkomitmen tinggi atau sangat tinggi untuk menerapkan di sekolah. Berdasarkan analisis terse- 
but, perlu adanya kegiatan tindak lanjut berupa pendampingan ke sekolah-sekolah sasaran untuk memastikan diterapkannya hasil workshop di sekolah.

Peserta menindaklanjuti workshop dengan kegiatan mandiri selama bulan Juni-Juli 2017 (setelah libur hari raya Idul Fitri 1438 H). Selanjutnya, pada tanggal 21 Juli 2017, tim pengabdian berkunjung ke tiga sekolah untuk melaksanakan pendampingan, yaitu (1) SMK Muhammadiyah 1 Patuk, (2) SMK Muhammadiyah 1 Playen, dan (3) SMK Muhammadiyah Wonosari.

Terdapat beberapa kendala yang dihadapi oleh guru di antaranya adalah (1) sukar meluangkan waktu untuk menyusun/memperbaiki dokumen silabus/RPP, (2) tidak adanya tuntutan sekolah untuk mengimplementasikan kurikulum 2013 dengan ideal serta tidak adanya tuntutan kenaikan pangkat membuat guru kurang termotivasi untuk meningkatkan kualitas perangkat pembelajaran (kasus SMK Muhammadiyah Wonosari), (3) kurangnya buku siswa kurikulum 2013 yang dapat diakses oleh siswa sehingga buku tidak dapat dibawa pulang oleh siswa (kasus SMK Muhammadiyah 1 Patuk), dan (4) ketidakmampuan siswa untuk mengikuti aktivitas pembelajaran yang diamanatkan pada buku siswa maupun buku guru sehingga membuat buku-buku tersebut tidak digunakan (kasus SMK Muhammadiyah 1 Playen).Simpulan dan Saran

Kesimpulan yang dapat diambil dari kegiatan ini adalah bahwa (1) workshop perencanaan pembelajaran dapat berjalan dengan lancar, (2) respon peserta terhadap pelaksanaan workshop sangat bagus, (3) terdapat kendala berupa keterbatasan daya dukung sekolah dan kurangnya motivasi guru untuk memperbaiki kualitas perangkat pembelajaran, (4) kendala tersebut diupayakan untuk diatasi dengan terus memberikan pendampingan kepada para guru hingga dihasilkan dokumen silabus dan RPP yang memadai.

Saran yang dapat direkomendasikan adalah (1) pada workshop serupa, perlu diupayakan penelitian pendahuluan sejauh mana peserta workshop mengimplementasikan kurikulum 2013 di sekolah, (2) workshop perlu dikemas dalam bentuk coaching clinic di mana peserta membawa dokumen silabus/RPP yang sudah dipunyai untuk dikaji dan diperbaiki bersama.

\section{UCAPAN TERIMA KASIH}

Tim pengabdian kepada masyarakat menyampaikan terima kasih kepada Lembaga Pengabdian kepada Masyarakat (LPM) Universitas Ahmad Dahlan yang telah mendanai, membina, dan memonitor kegiatan ini sehingga dapat berjalan lancar dan mencapai tujuan dengan baik. 
Diterbitkan oleh Lembaga Pengabdian kepada Masyarakat

Universitas Ahmad Dahlan Yogyakarta

\section{REFERENSI}

Amir, A. 2013. "Pengembangan Profesionalisme Guru dalam Pembelajaran melalui Model Lesson Study, Logaritma”. Jurnal Logaritma Tahun 2013, 1(2).

Dikdasmen PDM Gunungkidul. SMK Muhammadiyah 1 Wonosari meraih peringkat 1 se

Kabupaten Gunungkidul di tahun 2015. Tersedia di http://dikdasmen.pdmgunungkidul.org/.

Jalal, F. 2007. Sertifikasi Guru untuk Mewujudkan Pendidikan yang Bermutu. Medan: Universitas Negeri Medan.

Kemdikbud. 2013. Lampiran IV Permendikbud Nomor 81A Tahun 2013 tentang Pedoman Umum Implementasi Pembelajaran Berdasarkan Kurikulum 2013. Jakarta: Kemdikbud.

Kunandar. 2007. Guru Profesional Implementasi Kurikulum Tingkat Satuan Pendidikan (KTSP) dan Sukses dalam Sertifikasi Guru. Jakarta: PT. Rajagrafindo Persada.

Mulyasa, H, E. 2009. Implementasi Kurikulum Tingkat Satuan Pendidikan Kemandirian Guru dan Kepala Sekolah. Jakarta: Bumi Aksara. 
